\title{
Implementasi Asas Keterbukaan Dalam Proses Pembentukan Peraturan Daerah Dalam Rangka Otonomi Daerah Di Kabupaten Kendal
}

\author{
Iwan Sulistiyo $^{*}$, Widayati ${ }^{* *}$, Sri Kusriyah ${ }^{* * *}$
}

* Mahasiswa Program Magister (S2) Ilmu Hukum Fakultas Hukum UNISSULA Semarang, email
iwansulistiyo90@gmail.com
${ }^{* *}$ Dosen Fakultas Hukum UNISSULA Semarang
${ }^{* * *}$ Dosen Fakultas Hukum UNISSULA Semarang

\begin{abstract}
ABSTRAK
Dalam penelitian ini permasalahan yang akan dibahas yaitu: proses pembentukan peraturan daerah dalam rangka otonomi daerah di Kabupaten Kendal dan penerapan asas keterbukaan dalam proses pembentukan peraturan daerah di Kabupaten Kendal.

Pendekatan yang akan digunakan adalah pendekatan yang bersifat Yuridis Empiris. Penelitian yang berbasis pada inventarisasi hukum positif, penemuan azas-azas hukum dan penemuan hukum inconcretto, yang dilengkapi pengamatan operasionalisasi asas-asas hukum secara empiris di masyarakat.

Kesimpulan dari penilitian ini adalah belum tersedianya instrumen hukum yang dapat menjadi rule of game pelaksanaan asas keterbukaan, pola pendokumentasian yang belum terintegrasi dan faktor keterbatasan anggaran juga menjadi hambatan bagi diterapkannya asas keterbukaan dalam pembentukan peraturan daerah di Kabupaten Kendal. Eksistensi peraturan hukum daerah dalam pembentukannya oleh pemerintah daerah telah sesuai dengan asas-asas peraturan perundangundangan yang baik, sebagaimanan tertuang dalam Undang-Undang Nomor 12 Tahun 2011 tentang Pembentukan Peraturan Perundang-undangan. Asas keterbukaan telah diterapkan dalam pembentukan peraturan daerah oleh pemerintah daerah yang terdapat pada : usulan rancangan peraturan daerah yang berasal dari Pemerintah Daerah maupun Dewan Perwakilan Rakyat Daerah; proses pembuatan peraturan daerah secara terencana, terpadu dan sistematis.

Kata Kunci : Implementasi, Asas Keterbukaan, Pembentukan Peraturan Daerah, Otonomi Daerah
\end{abstract}

\section{ABSTRACT}

In this research the problems to be discussed are: the process of formulating regional regulations in the context of regional autonomy in Kendal Regency and the application of the principle of openness in the process of formation of local regulations in Kendal Regency.

The approach to be used is the Juridical Empirical approach. Research based on the inventory of positive law, the discovery of legal principles and the discovery of inconcretto law, complemented by observations of the operationalization of empirical legal principles in society.

The conclusion of this research is the unavailability of legal instrument that can become the rule of game of implementation of the principle of openness, un-integrated documentation pattern and budgetary constraint factor also become obstacle for the application of openness principle in the 
formation of Regional Regulation in Kendal Regency. The existence of regulation of local law in its formation by the local government has been in accordance with the principles of good legislation, in accordance with the Law of the Republic of Indonesia Number 12 Year 2011 on the Establishment of Laws and Regulations. The principle of democracy has been applied in the formation of local regulations by the government areas contained in: proposed draft local regulations derived from the Regional Government and the Regional People's Legislative Assembly; the process of making local regulations in a planned, integrated and systematic.

Keywords : Implementation, Principle of Openness, Formation of Regional Regulation, Regional Autonomy

\section{PENDAHULUAN}

Pembentukan peraturan daerah (Perda) untuk mendorong dan mengoptimalisasikan pembangunan daerah hanya dapat terwujud apabila pembentukan peraturan daerah didukung dengan cara dan metode yang sesuai dengan peraturan perundang-undangan, kebutuhan daerah dan kearifan lokal dengan sungguh-sungguh. Mengenai perundang-undangan atau pembuatan produk perundang-undangan, tidak satu negara pun dapat mengabaikannya, terlebih lagi pada Indonesia yang menyatakan dirinya sebagai negara hukum. Sebagai negara hukum, pemerintah mengemban tugas menyelenggarakan kesejahteraan umum, dimana negara atau pemerintah ikut campur dalam mengurusi kesejahteraan rakyat. Hal ini menjadi suatu yang absolut atau tidak terelakkan dalam negara hukum kesejahteraan (wafare state).

Sejak bergulirnya reformasi pada tahun 1998, kemudian disusul dengan amandemen UndangUndang Dasar (UUD) Negara Republik Indonesia Tahun 1945. Perubahan pertama UUD 1945 yang disahkan dalam sidang Umum Majelis Permusyawaratan Rakyat Republik Indonesia (MPR-RI) yang diselenggarakan dari tanggal 12 sampai dengan tanggal 19 Oktober 1999. Pengesahan naskah perubahan pertama dilaksanakan pada tanggal 19 Oktober 1999 dapat disebut sebagai tonggak sejarah yang berhasil mematahkan semangat konservatisme dan romantisme di sebagian kalangan masyarakat yang cenderung menyakralkan atau menjadikan UUD 1945 bagaikan sesuatu yang suci dan tidak boleh disentuh oleh ide-ide perubahan sama sekali. ${ }^{1}$

MPR-RI melalui sidang amandemen ke-2 pada tahun 2000 menetapkan keputusan dalam salah satu pasal yaitu Pasal 18 ayat (6) Undang-Undang Dasar 1945 bahwa, "Setiap Pemerintahan Daerah berhak menetapkan Peraturan Daerah". ${ }^{2}$ Ini berarti bahwa Pemerintahan Daerah memiliki kewenangan dalam membentuk Peraturan Daerah karena telah mendapat legitimasi secara konstitusional.

Adapun definisi Perencanaan Pembangunan Daerah berdasarkan Peraturan Pemerintah Nomor 8 Tahun 2008 tentang Tahapan, Tata Cara Penyusunan, Pengendalian dan Evaluasi Pelaksanaan Rencana Pembangunan Daerah adalah suatu proses penyusunan tahapan-tahapan kegiatan yang

\footnotetext{
${ }^{1}$ Jimly Asshiddiqie, Konstitusi dan konstitusionalisme Indonesia, Jakarta: Sinar Grafika,2009, hal., 216

2 Undang-Undang Dasar Negara Republik Indonesia 1945 menegaskan dalam Pasal 18 Ayat (6) bahwa setiap pemerintahan daerah memiliki kewenangan dalam menetapkan peraturan daerah.
} 
melibatkan berbagai unsur pemangku kepentingan didalamnya, guna pemanfaatan dan pengalokasian sumber daya yang ada dalam rangka meningkatkan kesejahteraan sosial dalam suatu lingkungan wilayah/daerah dalam jangka waktu tertentu. Oleh karenanya, SKPD pun juga diberikan amanat untuk menyusun penjabaran RPJMD dalam format jangka menengah ( 5 tahun) dan jangka pendek ( 1 tahun).

Rencana Strategis Satuan Kerja Perangkat Daerah (Renstra-SKPD) adalah dokumen perencanaan SKPD untuk periode 5 (lima) tahun yang disusun untuk:

a. Menjamin adanya konsistensi perencanaan dan pemilihan program dan kegiatan prioritas sesuai dengan kebutuhan masyarakat.

b. Menjamin komitmen terhadap kesepakatan program dan kegiatan yang di bahas secara partisipatif dengan melibatkan semua stakeholders pembangunan dan masyarakat Kabupaten Kendal.

c. Memperkuat landasan penentuan program dan kegiatan tahunan daerah secara kronologis, sistematis dan berkelanjutan.

Kendala yang sering terjadi, yakni ketika suatu perbuatan atau tindakan harus dilaksanakan namun perangkat hukum yang akan dijadikan landasan belum siap. Ketidaksiapan tersebut dapat terjadi karena : peraturan hukumnya tidak ada atau belum ada, peraturan hukumnya ada tetapi tidak lengkap, dan dapat pula terjadi peraturan hukumnya ada dan lengkap tetapi kabur penafsirannya, serta adsa juga yang sulit dilaksanakan. Kondisi keadaan demikian apabila sesuatu tindakan tetap dilakukan, maka akan membuka peluang bahwa tindakan yang bersangkutan dapat saja mempunyai resiko tidak sah dan akan memunculkan gejolak sosial. Guna mengantisipasi hal tersebut, pemerintah daerah perlu diberi kebebasan bertindak untuk mengantisipasi krisis kekosongan hukum dengan melakukan inisiatif membentuk peraturan hukum dengan harapan tindakan yang akan dilakukan menjadi legal.

Suatu hal yang sulit dipungkiri, bahwa penggunaan kebebasan bertindak yang berlebihan dapat membawa dampak negatif, yakni pemerintah dapat cinderung lebih mempergunakan kekuasaan dalam menjalankan tugasnya yang pada gilirannya dapat terseret atau terjebak pada kondisi Negara Kekuasaan (machtsstaat). Oleh karena itu untuk mengeliminasi tindakan pemerintah daerah dalam menjalankannya (political will) agar tidak terjebak pada kategori Negara Kekuasaan (machtsstaat), maka tindakan tersebut harus dikemas dalam produk hukum berupa peraturan daerah yang pada gilirannya dapat dikategorikan sebagai Negara Hukum (rechtsstaat). Dampak lainnya dari penggunaan kekuasaan yang berlebihan oleh pemerintah daerah dalam menjalankan tugasnya dapat melahirkan tindakan-tindakan negatif antara lain : tindakan tidak sesuai dengan kaidah hukum (on rechtsmatige overheidsdaad), tidak bersendikan wewenang (on bevoegdheid), sewenang-wenang (willekeur), menyalahgunakan wewenang (detournement de pouvoir), dan melampaui batas wewenang (ultra vires).

Sejalan dengan semakin populernya nuansa demokratisasi dalam berbagai bidang kehidupan bermasyarakat, berbangsa dan bernegara, termasuk juga dalam lingkup pemerintah daerah, sudah barang tentu nuansa demokratisasi tersebut juga masuk dalam proses pembentukan peraturan daerah. Eksistensi Undang-Undang Nomor 23 Tahun 2014 tentang Pemerintahan Daerah, di satu sisi memberikan peluang yang cukup luas kepada pemerintah daerah untuk membentuk peraturan daerah sesuai dengan kewenangannya. Peraturan hukum daerah itu dapat berupa peraturan daerah, 
peraturan kepala daerah dan keputusan kepala daerah. Di sisi lain penggunaan asas kebebasan yang berlebihan dapat mengantarkan pemerintah daerah terjebak pada suatu sikap kontra produktif atau negatif, yang dapat menghasilkan produk hukum berupa peraturan hukum daerah yang cacat hukum. Dengan demikian eksistensi asas kebebasan bertindak dalam sistem pemerintahan daerah bersifat dilematis, yakni di satu sisi dapat bersifat positif untuk mengantisipasi kekosongan peraturan hukum daerah, di sisi lain dapat bersifat negatif yakni menghasilkan produk hukum yang cacat hukum. Berkaitan dengan hal tersebut, untuk mengantisipasi agar produk hukum daerah yang berupa keputusan kepala daerah, peraturan kepala daerah dan peraturan daerah tidak terjebak sebagai produk hukum yang cacat hukum, maka pada setiap pembentukan peraturan hukum daerah senantiasa memperhatikan konsep Negara Hukum dan asas-asas umum peraturan perundangundangan yang baik.

Berdasarkan latar belakang di atas, maka perumusan permasalahan sebagai berikut :

1. Bagaimanakah proses pembentukan peraturan daerah dalam rangka otonomi daerah di Kabupaten Kendal ?

2. Bagaimana penerapan asas keterbukaan dalam proses pembentukan peraturan daerah di Kabupaten Kendal ?

\section{PEMBAHASAN}

\section{Proses Pembentukan Peraturan Daerah Dalam Rangka Otonomi Daerah Di Kabupaten Kendal}

Peraturan Daerah adalah sebagai dasar hukum untuk mengatur dan mengurus rumah tangganya sendiri (otonom). Urusan rumah tangga daerah berasal dua sumber yaitu otonomi daerah dan tugas pembantuan (madebewid). Peraturan Daerah dibidang otonomi adalah Peraturan Daerah yang bersumber dari kewenangan atribusi yakni kewenangan yang bersumber dari Undang-Undang, sementara Peraturan Daerah di bidang tugas pembantuan adalah Peraturan Daerah yang bersumber dari kewenangan delegasi. ${ }^{3}$

Apabila dalam satu kali masa sidang Gubernur atau Bupati/Walikota dan DPRD menyampaikan rancangan Perda dengan materi yang sama, maka yang dibahas adalah rancangan Perda yang disampaikan oleh DPRD, sedangkan rancangan Perda yang disampaikan oleh Gubernur atau Bupati/Walikota dipergunakan sebagai bahan persandingan. Program penyusunan Perda dilakukan dalam satu Program Pembentukan Peraturan Daerah, sehingga diharapkan tidak terjadi tumpang tindih dalam penyiapan satu materi Perda. Ada berbagai jenis Perda yang ditetapkan oleh Pemerintah Daerah Propinsi dan Kabupaten/Kota antara lain:
a. Pajak Daerah;
b. Retribusi Daerah;
c. Tata Ruang Wilayah Daerah (RTRW);
d. Anggaran Pendapatan dan Belanja Daerah (APBD);
e. Rencana Program Jangka Menengah Daerah (RPJMD);

\footnotetext{
${ }^{3}$ Sirajuddin, dkk, Legilslatif Drafting, Pelembagaan Metode Partisipatif Dalam Pembentukan Peraturan Perundangundangan, 2015, Penerbid, Setara Press, Malang, hal. 158
} 


\section{f. Perangkat Daerah;}

g. Pemerintahan Desa;

h. Pengaturan umum lainnya.

Pembentukan Perda yang baik harus berdasarkan pada asas pembentukan peraturan perundang- undangan sebagai berikut:

a. Kejelasan tujuan, yaitu bahwa setiap pembentukan peraturan perundang-undangan harus mempunyai tujuan yang jelas yang hendak dicapai.

b. Kelembagaan atau pejabat pembentuk yang tepat, yaitu setiap jenis peraturan perundangundangan harus dibuat oleh lembaga/pejabat pembentuk peraturan perundang-undangan yang berwenang dan dapat dibatalkan atau batal demi hukum bila dibuat oleh lembaga/pejabat yang tidak berwenang.

c. Kesesuaian antara jenis, hierarki dan materi muatan, yaitu dalam pembentukan peraturan perundang-undangan harus benar-benar memperhatikan materi muatan yang tepat dengan jenis peraturan perundang-undangan.

d. Dapat dilaksanakan, yaitu bahwa setiap pembentukan peraturan perundang-undangan harus memperhatikan efektifitas peraturan perundang-undangan tersebut di dalam masyarakat, baik secara filosofis, yuridis maupun sosiologis.

e. Kedayagunaan dan kehasilgunaan, yaitu setiap peraturan perundang-undangan dibuat karena memang benar-benar dibutuhkan dan bermanfaat dalam mengatur kehidupan bermasayarakat, berbangsa dan bernegara.

f. Kejelasan rumusan, yaitu setiap peraturan perundang-undangan harus memenuhi persyaratan teknis penyusunan, sistematika dan pilihan kata atau terminologi, serta bahasa hukumnya jelas dan mudah dimengerti sehingga tidak menimbulkan berbagai macam interpretasi dalam pelaksanaannya.

g. Keterbukaan, yaitu dalam proses pembentukan peraturan perundang-undangan mulai dari perencanaan, persiapan, penyusunan dan pembahasan bersifat transparan dan terbuka. Dengan demikian seluruh lapisan masyarakat mempunyai kesempatan seluas-luasnya untuk memberikan masukan dalam proses pembuatan peraturan perundang-undangan.

Di samping itu materi muatan Perda harus mengandung asas-asas sebagai berikut:

a. Asas pengayoman, bahwa setiap materi muatan Perda harus berfungsi memberikan perlindungan dalam rangka menciptakan ketentraman masyarakat.

b. Asas kemanusiaan, bahwa setiap materi muatan Perda harus mencerminkan perlindungan dan penghormatan hak-hak asasi manusia serta harkat dan martabat setiap warga negara dan penduduk Indonesia secara proporsional.

c. Asas kebangsaan, bahwa setiap muatan Perda harus mencerminkan sifat dan watak bangsa Indonesia yang pluralistik (kebhinnekaan) dengan tetap menjaga prinsip negara kesatuan Republik Indonesia.

d. Asas kekeluargaan, bahwa setiap materi muatan Perda harus mencerminkan musyawarah untuk mencapai mufakat dalam setiap pengambilan keputusan.

e. Asas kenusantaraan, bahwa setiap materi muatan Perda senantiasa memperhatikan kepentingan 
seluruh wilayah Indonesia dan materi muatan Perda merupakan bagian dari sistem hukum nasional yang berdasarkan Pancasila.

f. Asas Bhinneka Tunggal Ika, bahwa setiap materi muatan Perda harus memperhatikan keragaman penduduk, agama, suku dan golongan, kondisi daerah dan budaya khususnya yang menyangkut masalah-masalah sensitif dalam kehidupan bermasyarakat, berbangsa dan bernegara.

g. Asas keadilan, bahwa setiap materi muatan Perda harus mencerminkan keadilan secara proporsional bagi setiap warga negara tanpa kecuali.

h. Asas kesamaan kedudukan dalam hukum dan pemerintahan, bahwa setiap materi muatan Perda tidak boleh berisi hal-hal yang bersifat membedakan berdasarkan latar belakang, antara lain agama, suku, ras, golongan, gender atau status sosial.

i. Asas ketertiban dan kepastian hukum, bahwa setiap materi muatan Perda harus dapat menimbulkan ketertiban dalam masyarakat melalui jaminan adanya kepastian hukum.

j. Asas keseimbangan, keserasian dan keselarasan, bahwa setiap materi muatan Perda harus mencerminkan keseimbangan, keserasian dan keselarasan antara kepentingan individu dan masyarakat dengan kepentingan bangsa dan negara.

Dalam rangka tertib administrasi dan peningkatan kualitas produk hukum daerah, diperlukan suatu proses atau prosedur penyusunan Perda agar lebih terarah dan terkoordinasi. Hal ini disebabkan dalam pembentukan Perda perlu adanya persiapan yang matang dan mendalam, antara lain pengetahuan mengenai materi muatan yang akan diatur dalam Perda, pengetahuan tentang bagaimana menuangkan materi muatan tersebut ke dalam Perda secara singkat tetapi jelas dengan bahasa yang baik serta mudah dipahami, disusun secara sistematis tanpa meninggalkan tata cara yang sesuai dengan kaidah bahasa Indonesia dalam penyusunan kalimatnya.

Prosedur penyusunan ini adalah rangkaian kegiatan penyusunan produk hukum daerah sejak dari perencanaan sampai dengan penetapannya. Proses pembentukan Perda terdiri dari 3 (tiga) tahap, yaitu:

a. Proses penyiapan rancangan Perda yang merupakan proses penyusunan dan perancangan di lingkungan DPRD atau di lingkungan Pemda (dalam hal ini Raperda usul inisiatif). Proses ini termasuk penyusunan naskah inisiatif (initiatives draft), naskah akademik (academic draft) dan naskah rancangan Perda (legal draft).

b. Proses pembahasan di DPRD untuk mendapatkan persetujuan.

c. Proses pengesahan oleh Kepala Daerah dan pengundangan oleh Sekretaris Daerah.

Propemperda adalah instrumen perencanaan program pembentukan Peraturan Daerah Provinsi atau Peraturan Daerah Kabupaten/Kota yang disusun secara terencana, terpadu dan sistematis. Program Pembentukan Peraturan Daerah yang disingkat dengan Propemperda yakni Instrumen perencanaan program pembentukan Perda Provinsi dan Perda Kabupaten/Kota yang disusun secara terencana, terpadu dan sistematis. ${ }^{4}$

Proses legislasi atau pembentukan perda merupakan suatu proses interaksi dari berbagai aktor

\footnotetext{
${ }^{4}$ Pasal 1 Angka 13 Peraturan Menteri Dalam Negeri Nomor 80 Tahun 2015 Tentang Pembentukan Produk Hukum Daerah
} 
yang berada dalam suatu sistem. Cakupan proses interaksi ini bisa sangat luas atau sempit tergantung dengan klasifikasi kebijakan yang diformulasikan dalam pembentukan perda dan ada tidaknya inisiatif aktor untuk memperluas cakupannya. Aktor tersebut berinteraksi dalam proses legislasi yang tergambar dalam empat karakter proses legislasi, yaitu: ${ }^{5}$

a. Politik elit

b. Teknokratis atau akademis

c. Politik-publik

d. Proses administrasi

Dalam pembentukan peraturan daerah terkait dengan materi muatan yang dapat diatur. ${ }^{6}$ Pertama, perda tidak boleh bertentangan dengan peraturan perundang-undangan yang lebih tinggi. Salah satu materi muatan perda adalah menjabarkan lebih lanjut peraturan perundang-undangan yang lebih tinggi. Kedua, perda dapat mengatur materi muatan yang bertujuan menampung kondisi khusus daerah.

Pemerintahan daerah harus mengupayakan agar setiap perda yang dibentuk memberikan insentif bagi masyarakat di daerah agar lebih maju baik dari sisi perekonomian, pendidikan, kesehatan, pelayanan publik dan sebagainya. Namun, pembentukan perda hingga kini masih menemui beberapa kendala sehingga mudah ditemukan perda maupun raperda yang bermasalah. Dr. Wahiduddin Adams, menjelaskan bahwa munculnya perda dan raperda bermasalah antara lain disebabkan oleh (i) lemahnya sumber daya manusia (sistem pendukung legislasi) di daerah, (ii) lemahnya pembinaan dan sosialisasi dari pusat ke daerah, (iii) lemahnya pengawasan masyarakat (partisipasi) terhadap kinerja pemerintahan daerah, dan (iv) penyusunan perda masih dipengaruhi kepentingan jangka pendek (untuk meningkatkan PAD) serta mendahulukan kepentingan elit lokal. ${ }^{7}$

\section{Penerapan Asas Keterbukaan Dalam Proses Pembentukan Peraturan Daerah Di Kabupaten Kendal}

Keterbukaan pemerintahan merupakan prasyarat lahirnya sistem pemerintahan yang demokratis. Prinsip keterbukaan ini seharusnya mampu diterjemahkan secara nyata dalam berbagai aspek penyelenggaraan pemerintahan, termasuk pembentukan Peraturan Daerah. Penerapan asas keterbukaan secara konsisten dan konsekuen dalam proses pembentukan Peraturan Daerah akan menjadikan Peraturan Daerah yang dihasilkan dapat terlaksana secara efektif dan efisien. Jelas bahwa asas keterbukaan dalam proses pembentukan Peraturan Daerah memiliki peran dan fungsi yang penting bagi dihasilkannya suatu produk peraturan perundang-undangan yang berwatak responsif.

Dalam pelaksanaan otonomi daerah, pemerintah daerah membuat sejumlah peraturan daerah. Pertaturan daerah tersebut biasa disingkat dengan istilah perda. Perda bisa mengatur masalah administrasi, lingkungan hidup, ketertiban, pendidikan, sosial, dan lain-lain. Perda tersebut pada

\footnotetext{
${ }^{5}$ Aria Suyudi, et.al. "Studi Tata kelola Proses Legislasi Daerah" Jakarta: Pusat Studi Hukum dan Kebijakan Indonesia (PSHK), 2009. Hal. 93.

${ }^{6}$ Materi muatan perda berisi materi muatan dalam rangka penyelenggaraan otonomi daerah dan tugas pembantuan serta menampung kondisi khusus daerah dan/atau penjabaran lebih lanjut peraturan perundang-undangan yang lebih tinggi.

7 Dr. Wahiduddin Adams, "Peta Permasalahan dalam Pembentukan Peraturan Daerah dan Upaya Fasilitasi Perancangan Peraturan Daerah" djpp.go.id.
} 
dasarnya dibuat untuk kepentingan masyarakat. Proses penyusunan peraturan daerah melalui beberapa tahap. Penyusunan peraturan daerah dimulai dengan perumusan masalah yang akan diatur dalam perda tersebut. Masalah yang dimaksud adalah masalah-masalah sosial atau publik. Pada umumnya masalah sosial dapat dibedakan menjadi 2 jenis, yaitu sebagai berikut:

a. Masalah sosial yang terjadi karena adanya perilaku dalam masyarakat yang bermasalah. Misalnya: maraknya perjudian atau beredarnya minuman keras dalam masyarakat sehingga membuat kehidupan masyarakat terganggu.

b. Masalah sosial yang disebabkan karena aturan hukum yang tidak lagi proporsional dengan keadaan masyarakat. Misalnya, perda tentang retribusi pemeriksaan kesehatan yang sangat memberatkan masyarakat kecil sehingga peraturan daerah tersebut harus diganti.

Pembuatan Perda dilakukan secara bersama-sama oleh Gubernur/Bupati/Walikota dengan DPRD Tingkat I dan II. Mekanisme pembuatannya adalah sebagai berikut:

1) Pertama, Pemerintah daerah tingkat I atau II mengajukan Rancangan Perda kepada DPRD melalui Sekretaris DPRD I atau II.

2) Kedua, Sekretaris DPRD mengirim Rancangan Perda kepada pimpinan DPRD tingkat I atau II.

3) Ketiga, Pimpinan DPRD tingkat I atau II mengirimkan Rancangan Perda tersebut kepada komisi terkait.

4) Keempat, Pimpinan komisi membentuk panitia khusus (pansus) untuk membahas Rancangan Perda usulan pemerintah atau inisiatif DPRD tingkat I atau II.

5) Kelima, Panitia khusus mengadakan dengar pendapat (publik hearing) dengan elemen-elemen yang meliputi unsur pemerintah, profesional, pengusaha, partai politik, Lembaga Swadaya Masyarakat, ormas, Organisasi Kepemudaan, tokoh masyarakat, dan unsur lain yang terkait di daerah.

6) Keenam, DPRD tingkat I atau II mengadakan sidang paripurna untuk mendengarkan pandangan umum dari fraksi-fraksi yang selanjutnya menetapkan Rancangan Perda menjadi Perda. ${ }^{8}$

Pembentukan Perda yang baik harus berdasarkan pada asas pembentukan peraturan perundang-undangan sebagai berikut:

a. Kejelasan tujuan, yaitu bahwa setiap pembentukan peraturan perundang-undangan harus mempunyai tujuan yang jelas yang hendak dicapai.

b. Kelembagaan atau pejabat pembentuk yang tepat, yaitu setiap jenis peraturan perundangundangan harus dibuat oleh lembaga/pejabat pembentuk peraturan perundang-undangan yang berwenang dan dapat dibatalkan atau batal demi hukum bila dibuat oleh lembaga/pejabat yang tidak berwenang.

c. Kesesuaian antara jenis, hierarki dan materi muatan, yaitu dalam pembentukan peraturan perundang-undangan harus benar-benar memperhatikan materi muatan yang tepat dengan jenis peraturan perundang-undangan.

d. Dapat dilaksanakan, yaitu bahwa setiap pembentukan peraturan perundang-undangan harus memperhatikan efektifitas peraturan perundang-undangan tersebut di dalam masyarakat, baik secara filosofis, yuridis maupun sosiologis.

\footnotetext{
${ }^{8}$ Srijanti \& A. Rahman. Etika Berwarga Negara (ed.2). (Jakarta: Salemba Empat, 2008). hal 106-107
} 
e. Kedayagunaan dan kehasilgunaan, yaitu setiap peraturan perundang-undangan dibuat karena memang benar-benar dibutuhkan dan bermanfaat dalam mengatur kehidupan bermasayarakat, berbangsa dan bernegara.

f. Kejelasan rumusan, yaitu setiap peraturan perundang-undangan harus memenuhi persyaratan teknis penyusunan, sistematika dan pilihan kata atau terminologi, serta bahasa hukumnya jelas dan mudah dimengerti sehingga tidak menimbulkan berbagai macam interpretasi dalam pelaksanaannya.

g. Keterbukaan, yaitu dalam proses pembentukan peraturan perundang-undangan mulai dari perencanaan, persiapan, penyusunan dan pembahasan bersifat transparan dan terbuka. Dengan demikian seluruh lapisan masyarakat mempunyai kesempatan seluas-luasnya untuk memberikan masukan dalam proses pembuatan peraturan perundang-undangan.

Di samping itu materi muatan Perda harus mengandung asas-asas sebagai berikut:

a. asas pengayoman,

b. asas kemanusiaan,

c. asas kebangsaan,

d. asas kekeluargaan,

e. asas kenusantaraan,

f. asas bhinneka tunggal ika,

g. asas keadilan,

h. asas kesamaan dalam hukum dan pemerintahan,

i. asas ketertiban dan kepastian hukum,

j. asas keseimbangan, keserasian dan keselarasan,

k. asas lain sesuai substansi Perda yang bersangkutan.

Selain asas dan materi muatan di atas, DPRD dan Pemerintah Daerah dalam menetapkan Perda harus mempertimbangkan keunggulan lokal /daerah dan kaearifan lokal, sehingga perda yang dihasilkan mempunyai daya guna dan dapat mesejahterakan masyarakat.

\section{PENUTUP}

\section{Kesimpulan}

Berdasarkan hasil penelitian dan pembahasan maka dapat ditarik kesimpulan sebagai berikut:

1. Belum tersedianya instrumen hukum yang dapat menjadi rule of game pelaksanaan asas keterbukaan, pola pendokumentasian yang belum terintegrasi dan faktor keterbatasan anggaran juga menjadi hambatan bagi diterapkannya asas keterbukaan dalam pembentukan Peraturan Daerah di Kabupaten Kendal.

2. Eksistensi pembentukan peraturan daerah oleh Pemerintah Daerah Kabupaten Kendal belum sesuai dengan asas-asas Peraturan perundang-undangan yang baik terutama terkait dengan asas keterbukaan, sesuai dengan Undang-Undang Nomor 12 Tahun 2011 tentang Pembentukan Peraturan Perundang-undangan.

\section{Saran}


1. Guna mewujudkan peraturan daerah yang baik dan demokratis, Pemerintah Daerah agar bekerja sama dengan akademisi/pakar Peraturan perundang-undangan melakkukan pelatihan/training tentang penyusunan peraturan perundang-undangan sehingga dapat meningkatkan capacity building anggota DPRD maupun Kepala Daerah;

2. Partisipasi masyarakat dalam pembentukan Peraturan Daerah perlu ditingkatkan dalam rangka good governance dengan adanya sistem komunikasi dengan media massa sehingga fungsi kontrol berjalan baik dan keinginan masyarakatpun terpenuhi.

\section{DAFTAR PUSTAKA}

Aria Suyudi, et.al. "Studi Tata kelola Proses Legislasi Daerah" Jakarta: Pusat Studi Hukum dan Kebijakan Indonesia (PSHK), 2009. Hal. 93.

Dr. Wahiduddin Adams, "Peta Permasalahan dalam Pembentukan Peraturan Daerah dan Upaya Fasilitasi Perancangan Peraturan Daerah" djpp.go.id.

http://gumilar69.blogspot.com/2013/10/makalah-pembentukan-perda-peraturan.html

Jimly Asshiddiqie, Konstitusi dan konstitusionalisme Indonesia, Jakarta: Sinar Grafika, 2009, hal., 216

Materi muatan perda berisi materi muatan dalam rangka penyelenggaraan otonomi daerah dan tugas pembantuan serta menampung kondisi khusus daerah dan/atau penjabaran lebih lanjut peraturan perundang-undangan yang lebih tinggi.

Pasal 1 Angka 13 Peraturan Menteri Dalam Negeri Nomor 80 Tahun 2015 Tentang Pembentukan Produk Hukum Daerah

Sirajuddin, dkk, Legilslatif Drafting, Pelembagaan Metode Partisipatif Dalam Pembentukan Peraturan Perundang-undangan, 2015, Penerbid, Setara Press, Malang, hal. 158

Srijanti \& A. Rahman. Etika Berwarga Negara (ed.2). (Jakarta: Salemba Empat, 2008). hal 106-107

Tavip Agus Riyanto, Menggagas Strategi Reformasi Birokrasi Untuk Mewujudkan Pemerintahan Efektif dan Akuntabel, dalam Agus Pramusinto dan Erwan Agus Purwanto (edt), 2009, Reformasi Birokrasi, Kepemimpinan dan Pelayanan Publik: Kajian tentang pelaksanaan Otonomi Daerah di Indonesia, Yogyakarta: Gaya Media, JIAN-UGM, MAP-UGM. hal., 56

Undang-Undang Dasar Negara Republik Indonesia 1945 menegaskan dalam Pasal 18 Ayat (6) bahwa setiap pemerintahan daerah memiliki kewenangan dalam menetapkan peraturan daerah. 